\title{
Ribonucleic Acid of Chloramphenicol-Treated Shigella flexneri
}

\author{
By R. B. YEE AND H. M. GEZON \\ Graduate School of Public Health, University of Pittsburgh, \\ Pittsburgh 13, Pennsylvania, U.S.A.
}

\begin{abstract}
SUMMARY
Resting organisms of Shigella flexneri serotype 3 are able to synthesize soluble and ribosomal ribonucleic acid (RNA) in the presence of chloramphenicol. The antibiotic stimulates the synthesis of soluble RNA but has no apparent effect on ribosomal RNA production. In contrast, chlortetracycline, which also suppresses formation of protein, stimulates soluble RNA synthesis and inhibits ribosomal RNA synthesis. The soluble RNA of the chloramphenicol-treated organisms possesses amino acid accepting activity comparable to that of the soluble RNA of untreated organisms. The findings indicate that chloramphenicol does not promote the synthesis of biologically inactive soluble RNA. The stimulation of soluble RNA synthesis appears to be the result, rather than the cause, of the inhibition of protein production by the antibiotic.
\end{abstract}

\section{INTRODUCTION}

Protein synthesis in bacteria is inhibited markedly by chloramphenicol; in contrast, ribonucleic acid (RNA) synthesis is not affected and may even be stimulated (Gale \& Folkes, 1953; Wisseman, Smadel, Hahn \& Hopps, 1954). Since RNA plays a major role in the production of protein (Chantrenne, 1961), it has been postulated that the inhibitory action of chloramphenicol is the result of the formation of nonfunctional RNA (Gale, 1958; Ramsey, 1958). The results of some of the studies of the RNA of chloramphenicol-treated Escherichia coli suggest that this nucleic acid is 'abnormal' and perhaps physiologically inactive. Neidhardt \& Gros (1957) showed that the RNA produced in the presence of chloramphenicol, 'chloramphenicol-RNA', was unstable, being degraded when the treated organisms were placed in chloramphenicol-free medium. Other workers have shown that chloramphenicol-RNA was present in ribonucleoprotein particles of sizes smaller than those present in untreated organisms (Dagley \& Sykes, 1959; Nomura \& Watson, 1959). Horiuchi, Horiuchi \& Mizuno (1959) observed that, after being washed and resuspended in drug-free medium, chloramphenicol-treated Escherichia coli showed a lag period before beginning to synthesize protein. The authors conclude that chloramphenicol-RNA does not participate in protein synthesis.

Evidence that chloramphenicol-RNA is similar to the RNA of untreated organisms has been reported; Pardee \& Prestidge (1956) found that the base composition of both types of RNA was the same. Aronson \& Spiegelman (1961) showed that chloramphenicol-RNA was converted to a stable form when chloramphenicoltreated Escherichia coli was resuspended in a medium which permitted rapid protein formation. They also presented data which demonstrated that organisms con- 
taining chloramphenicol-RNA produced protein without any detectable nucleic acid synthesis. The authors have proposed that chloramphenicol-RNA is not abnormal but is a normal unstable intermediate of ribonucleoprotein and that chloramphenicol blocks the conversion of the intermediate to a stable form.

We have made experiments designed to characterize further the synthesis of RNA in the presence of chloramphenicol and the biological activity of some of the RNA. A previous study showed that chloramphenicol stimulated RNA production in resting Shigella flexneri serotype 3 (Yee, Pan \& Gezon, 1962). The present paper presents evidence which indicates that the soluble RNA synthesis and not the ribosomal RNA synthesis in this organism is stimulated by chloramphenicol and that the soluble RNA can bind amino acids. A preliminary report of some of the findings was published elsewhere (Yee, Gezon \& McElligott, 1962).

\section{METHODS}

Cultivation and starvation of organisms. Shigella flexneri serotype 3 strain B-1003 (Pan, Yee \& Gezon, 1957) was used. The previously described methods for growing, starving and harvesting the organisms in phosphate buffered saline ( $\mathrm{pH} 6.9$ ) to prepare resting suspensions (Yee, Pan \& Gezon, 1962) were modified as follows, mainly to accommodate the large volume of organisms required: (1) a sufficient quantity of organism was obtained by growing them in flasks containing 3.5 l. defined medium; (2) each flask was seeded with $5 \mathrm{ml}$. of an $18 \mathrm{hr}$. starter culture which had been inoculated with a loopful of growth from a defined-medium slope culture; (3) cultures were aerated on a rotary shaker; (4) the defined medium with glucose as carbon and energy source and ammonium monobasic phosphate as nitrogen source did not contain nicotinamide since this was not needed for optimum growth of the organism (Pan, Yee \& Gezon, 1962).

Treatment with chloramphenicol. Defined medium containing L-aspartic acid as sole nitrogen source was used to obtain maximum RNA synthesis. The starved organisms were resuspended in the medium described before (Yee, Pan \& Gezon, 1962). Equal volumes of suspension were added to each of three flasks. One flask serving as a $0 \mathrm{hr}$., or unincubated, control was centrifuged immediately in a refrigerated Sharples supercentrifuge. Chloramphenicol was added to the second flask to final concentration $2 \mu \mathrm{g} . / \mathrm{ml}$; the third flask was used as a chloramphenicol-free control. The latter two flasks were incubated at $37^{\circ}$ on a rotary shaker for $4 \mathrm{hr}$. and the organisms then collected on a Sharples supercentrifuge and stored at $-20^{\circ}$.

Separation of soluble and ribosomal $R N A$. A procedure based on the method of Tissières, Watson, Schlessinger \& Hollingworth (1959) was used. The organisms were disrupted by grinding in a mortar with alumina A301 and extracted with 0.01 MTris(hydroxymethyl)aminomethane buffer $(\mathrm{pH} \mathrm{7 \cdot 4}$ ) containing $0.01 \mathrm{M}$-magnesium acetate to minimize degradation of ribosomal particles. Alumina, whole organisms and cell debris were removed by centrifugation at $6000 \mathrm{~g}$ at $0^{\circ}$. The resulting crude extract was centrifuged at $100,000 \mathrm{~g}$ for $120 \mathrm{~min}$. to sediment ribosomal RNA. The upper third of the supernatant fluid was removed for analysis of soluble RNA; RNA and protein were precipitated with cold $5 \%(\mathrm{w} / \mathrm{v})$ trichloroacetic acid. The RNA was extracted from the precipitates with hot trichloroacetic acid by the method of Gale \& Folkes (1953) and measured by the orcinol reaction (Schneider, 1957) with adenosine-5'-monophosphate as standard. 
Isolation of soluble RNA. Soluble RNA was isolated by phenol treatment of supernatant fluids of crude extracts obtained after centrifugation at $100,000 \mathrm{~g}$ (Tissières, 1959). Polysaccharide was removed from the RNA preparations by treatment with 2-methoxyethanol (Kirby, 1956). The RNA was stored at $-20^{\circ}$.

Amino acid accepting activity. The total amino acid accepting activity of the soluble RNA of untreated and of chloramphenicol-treated organisms was measured by the assay system of Berg \& Ofengand (1958) using a ${ }^{14} \mathrm{C}$ algal protein hydrolysate as a source of labelled amino acids. After incubation the soluble RNA was re-isolated (Ofengand, Dieckmann \& Berg, 1961) and its radioactivity measured in a Nuclear-Chicago counter equipped with a Micromil window. The ability of the soluble RNA preparations to accept individual amino acids was determined by the method of Brown (1960). The amino acid + RNA complexes were removed from the reaction system by charcoal (Norite $\mathbf{A}$ ) adsorption and re-isolated by phenol treatment of the charcoal. The amino acids were released from the soluble RNA at $\mathrm{pH} 10$ and separated by two-dimensional paper chromatography. Butanol+water + glacial acetic acid $(60+25+15$, by vol.), and water-saturated phenol containing $0.002 \%$ 8-hydroxyquinoline in an atmosphere of ammonia, were used as solvents. Development in each solvent was for $24 \mathrm{hr}$. The amino acid spots were located with ninhydrin, cut out, eluted with $10 \%(\mathrm{v} / \mathrm{v})$ isopropanol in water and the radioactivity of the solutions measured.

\section{RESULTS}

Effect of chloramphenicol on the synthesis of soluble and ribosomal RNA. Experiments were made to determine whether soluble and/or ribosomal RNA synthesis was stimulated by chloramphenicol. Initially attempts were made to extract soluble RNA from dried organisms of untreated and chloramphenicol-treated Shigella flexneri with hot sodium dodecylsulphate by the method of Ofengand et al. (1961). However most of the RNA of the organisms was removed, indicating that ribosomal RNA also was present in the preparations. Fractionation of lysates of spheroplasts also was unsuccessful. The bulk of the cellular RNA was found in the supernatant fluids of the lysates after centrifugation at $100,000 \mathrm{~g}$.

A procedure which used alumina grinding to disrupt the organisms was found to be suitable. The organisms were able to synthesize both soluble and ribosomal RNA in the presence of chloramphenicol (Table 1). This finding is consistent with those reported for Escherichia coli (Nomura \& Watson, 1959; Aronson \& Spiegelman, 1961). In addition, soluble RNA production in resting Shigella flexneri was stimulated by chloramphenicol whereas ribosomal RNA production appeared to be unaffected. As a result, the chloramphenicol-treated organisms possessed low ribosomal RNA: soluble RNA ratios. It should be pointed out that the degree of RNA synthesis varied with different preparations; however, the ratios were relatively constant and reproducible.

The cell-wall and membrane fractions of the disrupted organisms were also examined. The RNA content of the fractions was less than $0.5 \%$ of the total cellular RNA and no detectable increase occurred during the incubation of untreated or chloramphenicol-treated organisms.

Effect of chlortetracycline on RNA synthesis. Chlortetracycline also inhibits protein synthesis (Gale \& Folkes, 1953). The action of this antibiotic on RNA synthesis 
was compared to that of chloramphenicol. The results indicated that the observed effect of chloramphenicol on RNA synthesis was not a non-specific one, i.e. antibiotics which inhibited protein synthesis might not be similar in their action on

\section{Table 1. Effect of chloramphenicol on RNA synthesis by resting \\ Shigella flexneri serotype $\mathbf{3}$}

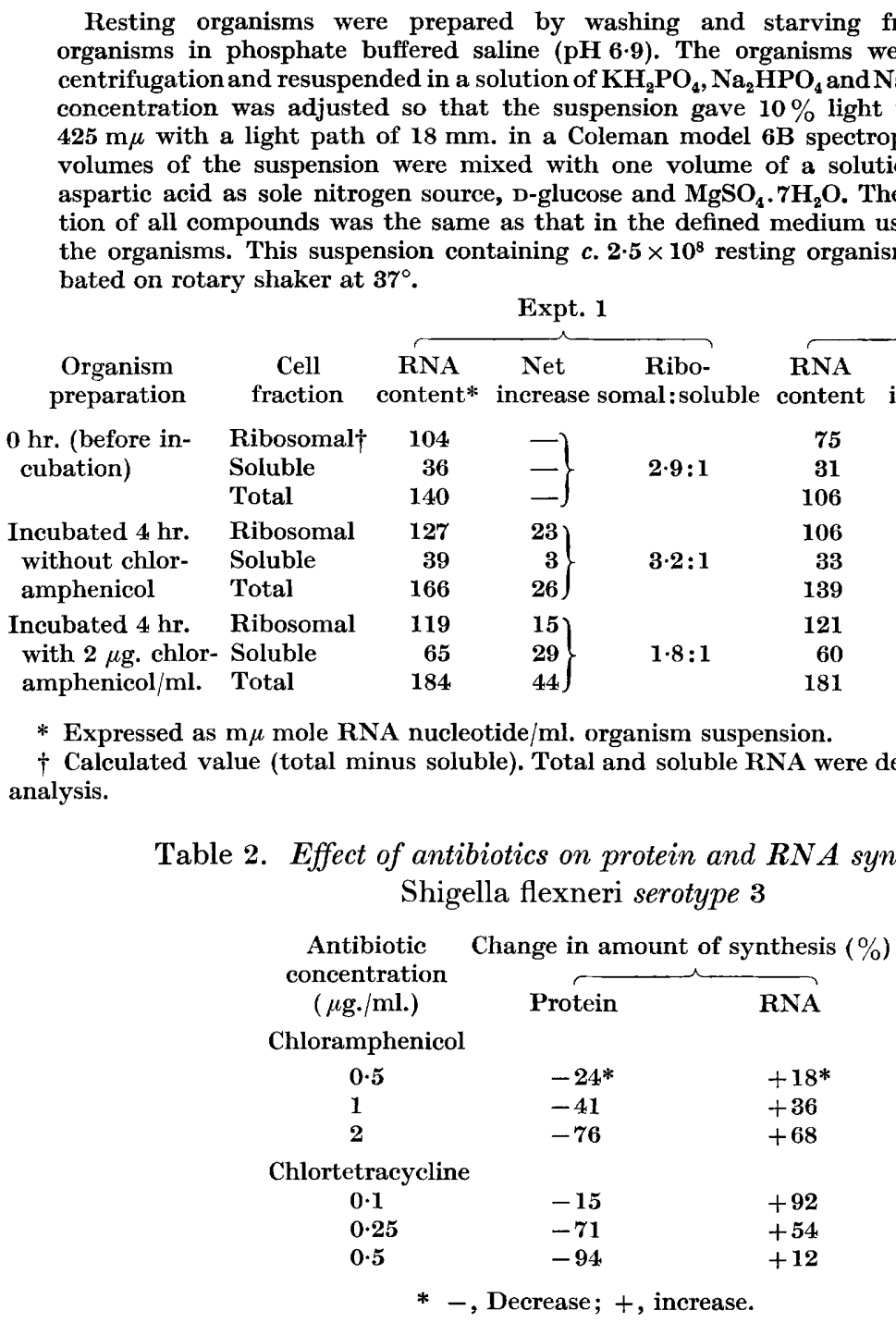

RNA synthesis. The effect of chlortetracycline on protein and RNA synthesis is shown in Table 2 ; the action of chloramphenicol is shown for comparison. Concentrations of chlortetracycline less than the minimum required for complete inhibition of protein synthesis and cell multiplication stimulated RNA synthesis. As the chlortetracycline concentration was increased the degree of stimulation 
decreased, contrary to the finding with chloramphenicol. Also, chlortetracycline not only stimulated soluble RNA synthesis but also decreased the production of ribosomal RNA ('Table 3).

Table 3. Effect of chlortetracycline on $R N A$ synthesis by resting

Shigella flexneri serotype 3

\begin{tabular}{|c|c|c|}
\hline Organism preparation & $\begin{array}{c}\text { Cell } \\
\text { fraction }\end{array}$ & $\begin{array}{c}\text { Net increase, } \\
\text { m } \mu \text { mole RNA } \\
\text { nucleotide/ml. } \\
\text { suspension }\end{array}$ \\
\hline Incubated $4 \mathrm{hr}$. without antibiotic & $\begin{array}{l}\text { Ribosomal } \\
\text { Soluble } \\
\text { Total }\end{array}$ & $\begin{array}{c}105 \\
17 \\
122 \\
(3 \cdot 8: 1)^{*}\end{array}$ \\
\hline Incubated $4 \mathrm{hr}$. with antibiotic & $\begin{array}{l}\text { Ribosomal } \\
\text { Soluble } \\
\text { Total }\end{array}$ & $\begin{array}{c}55 \\
50 \\
105 \\
(1 \cdot 8: 1)\end{array}$ \\
\hline
\end{tabular}

Table 4. Amino acid accepting ability of soluble $R N A$ of untreated and chloramphenicol-treated Shigella flexneri serotype $\mathbf{3}$

* Numbers in parentheses represent ratio of ribosomal RNA to soluble RNA.

Organism suspension and incubation same as in Table 1. Chlortetracycline concentration, $0.5 \mu \mathrm{g} . / \mathrm{ml}$.

\begin{tabular}{|c|c|c|c|}
\hline \multirow[b]{2}{*}{ Source of soluble RNA } & \multicolumn{3}{|c|}{ RNA preparations } \\
\hline & $\mathbf{I}$ & II & III \\
\hline Untreated organisms & $1877 *$ & 2400 & 1833 \\
\hline Chloramphenicol-treated organisms & 2163 & 2300 & 1900 \\
\hline
\end{tabular}

Table 5. Amino acid accepting ability

\begin{tabular}{|c|c|c|}
\hline \multirow[b]{2}{*}{ Amino acid } & \multicolumn{2}{|c|}{ Source of soluble RNA } \\
\hline & $\begin{array}{l}\text { Untreated } \\
\text { organisms }\end{array}$ & $\begin{array}{c}\text { Chloramphenicol- } \\
\text { treated } \\
\text { organisms }\end{array}$ \\
\hline $\begin{array}{l}\text { Leucine } \\
\text { Isoleucine } \\
\text { Phenylalanine }\end{array}$ & $41 \cdot 2 *$ & $39 \cdot 0$ \\
\hline Tyrosine & $19 \cdot 3$ & $20 \cdot 6$ \\
\hline Arginine & $8 \cdot 0$ & $8 \cdot 6$ \\
\hline Valine & $\mathbf{3 \cdot 9}$ & $5 \cdot 0$ \\
\hline Glutamic & $\mathbf{5 \cdot 0}$ & $5 \cdot 8$ \\
\hline Aspartic & 4.7 & $4 \cdot 6$ \\
\hline Histidine & $\mathbf{3 \cdot 9}$ & $\mathbf{3 \cdot 5}$ \\
\hline Alanine & $4 \cdot 0$ & $4 \cdot 4$ \\
\hline Glycine & $\mathbf{2 \cdot 5}$ & $2 \cdot 0$ \\
\hline Serine & $2 \cdot 0$ & $1 \cdot 8$ \\
\hline Proline & $\mathbf{2 \cdot 0}$ & $\mathbf{1} \cdot \mathbf{9}$ \\
\hline Threonine & $1 \cdot 8$ & $\mathbf{1 . 5}$ \\
\hline Lysine & $1 \cdot 7$ & $1 \cdot 5$ \\
\hline
\end{tabular}


Amino acid accepting ability. Soluble RNA mediates protein synthesis by binding amino acids and transporting them to the ribosomes where peptide bonding occurs (Chantrenne, 1961). The production of non-functional RNA may cause diminution of protein synthesis. Eaton \& Caffrey (1961) reported that the soluble RNA formed by Escherichia coli in the presence of dihydrostreptomycin was unable to accept amino acids. It seemed feasible to test the soluble RNA produced by chloramphenicol-treated Shigella flexneri (soluble chloramphenicol-RNA). As a working hypothesis it was assumed that the stimulation of soluble RNA synthesis by chloramphenicol might be an indication that the nucleic acid was 'abnormal' and physiologically inactive. As shown in Table 4, the soluble chloramphenicol-RNA had a total amino acid accepting ability which was comparable to that of the soluble RNA of untreated organisms. Similar results were obtained when the accepting ability for individual amino acids was determined (Table 5). These findings indicate that chloramphenicol does not induce the formation of nonfunctional soluble RNA in $S$. flexneri serotype $\mathbf{3}$.

\section{DISCUSSION}

The conclusion that chloramphenicol stimulates soluble RNA synthesis is based on the observation that resting chloramphenicol-treated Shigella flexneri had a higher soluble RNA content than untreated resting organisms. Alternative explanations which might be given for this finding can be excluded. The resting suspensions were prepared by washing and starving the organisms in phosphate buffer saline. This solution was used in an earlier study in which the stimulation of total RNA synthesis in $S$. flexneri by chloramphenicol was shown (Yee et al. 1962a). The starvation of the organisms in a magnesium-free medium may have resulted in a lower ribosomal RNA : soluble RNA ratio, indicating that degradation of ribosomes may occur. This did not affect the results. Chloramphenicol-treated organisms which had been washed and starved in a magnesium-containing solution to maintain the integrity of the ribosomes also had a higher soluble RNA content than untreated organisms (Yee et al. 1962b).

The use of alumina grinding to disrupt the organisms may have introduced an error. Aronson \& Spiegelman (1961) reported that the use of this method to disrupt Escherichia coli resulted in the release of some of the ribosomal chloramphenicolRNA into the soluble fraction. In addition, the observed increase in the soluble RNA of chloramphenicol-treated Shigella flexneri may be attributed to degradation of the ribosomal RNA in the organisms as a result of exposure to the antibiotic, or to the inability of the treated organisms to assemble newly formed ribosomal RNA subunits. However, the amino acid accepting activities of soluble chloramphenicolRNA and soluble RNA of untreated organisms are similar. The above alternative explanations would require the unlikely assumption that functional soluble RNA is a degradation product or a precursor of ribosomal RNA. Lacks \& Gros (1959) were unable to show any conversion of soluble RNA to ribosomal RNA. On the basis of this finding and the difference in the base composition of the two types of RNA, they concluded that soluble RNA is not a precursor of ribosomal RNA. The difference in base composition also casts doubt on functional soluble RNA as being a degradation product of ribosomal nucleic acid. It thus seems likely that chloramphenicol stimulates soluble RNA synthesis in resting $S$. flexneri serotype 3 . 
The demonstrated activity of soluble chloramphenicol-RNA suggests that the stimulatory action is the result, rather than the cause, of the blockage of protein synthesis by the drug. A suppression of protein production may result in the channelling of available nitrogen into RNA (Fraenkel \& Neidhardt, 1961). The results thus indicate it is doubtful that chloramphenicol inhibits protein synthesis by inducing the production of physiologically inactive 'abnormal' RNA or by altering the activity of RNA.

This investigation was carried out under the sponsorship of the Commission on Enteric Infections, U.S. Armed Forces Epidemiological Board and financially supported by the Surgeons General, Department of the Army and Department of the Navy. We are grateful to Parke, Davis and Co. for the supply of chloramphenicol and to the Aluminum Co. of America for the supply of alumina A301. We also wish to thank Dr Ivy McManus, Department of Biochemistry and Nutrition, for her helpful suggestions and Mrs Maryke Smulders for technical assistance.

\section{REFERENCES}

Aronson, A. I. \& Spiegelman, S. (1961). On the nature of the ribonucleic acid synthesized in the presence of chloramphenicol. Biochim. biophys. Acta, 53, 84 .

Berg, P. \& Ofengand, E. J. (1958). An enzymatic mechanism for linking amino acids to RNA. Proc. nat. Acad. Sci., Wash. 44, 78.

Brown, G. L. (1960). DNA and specific protein synthesis. In Microbial Genetics. Symp. Soc. gen. Microbiol. 10, 208.

Chantrenne, H. (1961). The Biosynthesis of Proteins. New York: Pergamon Press.

DAGLeY, S. \& SyKES, J. (1959). Effect of drugs upon components of bacterial cytoplasm. Nature, Lond. 183, 1608.

Eaton, N. R. \& Caffrey, R. (1961). Effect of dihydrostreptomycin on Escherichia coli. J. Bact. 81, 918.

Fraenkel, D. G. \& Neidhardt, F. C. (1961). Use of chloramphenicol to study control of RNA synthesis in bacteria. Biochim. biophys. Acta, 53, 96.

Gale, E. F. \& Folkes, J. P. (1953). The assimilation of amino-acids by bacteria. 15. Actions of antibiotics on nucleic acid and protein synthesis in Staphylococcus aureus. Biochem. J. 53, 493.

GaLe, E. F. (1958). Specific inhibitors of protein synthesis. In The Strategy of Chemotherapy: Symp. Soc. gen. Microbiol. 8, 212.

Horiuchi, T., Horruchi, S. \& Mizuno, D. (1959). Non-participation in protein synthesis of the RNA synthesized in the presence of chloramphenicol in Escherichia coli. Jap. J. med. Sci. Biol. 12, 99.

KrnBy, K. S. (1956). A new method for the isolation of ribonucleic acids from mammalian tissues. Biochem. J. 64, 405.

LACKs, S. \& Gros, F. (1959). A metabolic study of the RNA-amino acid complexes in Escherichia coli. J. molec. Biol. 1, 301.

Niminardt, F. C. \& Gros, F. (1957). Metabolic instability of the ribonucleic acid synthesized by Escherichia coli in the presence of chloromycetin. Biochim. biophys. Acta, $25,513$.

Nomura, M. \& Watson, J. D. (1959). Ribonucleoprotein particles within chloromycetininhibited Escherichia coli. J. molec. Biol. 1, 204.

Ofengand, E. J., Dieckmann, M. \& Berg, P. (1961). The enzymic synthesis of amino acyl derivatives of ribonucleic acid. III. Isolation of amino acid-acceptor ribonucleic acids from Escherichia coli. J. biol. Chem. 236, 1741.

Pan, S. F., Yee, R. B. \& Gezon, H. M. (1957). Studies on the metabolism of Shigella. I. The occurrence of a tricarboxylic acid cycle in Shigella flexneri. J. Bact. 73, 402. 
Pan, S. F., YeE, R. B. \& Gezon, H. M. (1962). Studies on the metabolism of Shigella. IV. Nutritional requirements of Shigella flexneri serotype 3. J. Bact. 83, 61.

Pardee, A. B. \& Prestidge, L. S. (1956). The dependence of nucleic acid syntheses on the presence of amino acids in Escherichia coli. J. Bact. 71, 677.

Ramsey, H. H. (1958). Protein synthesis as a basis for chloramphenicol-resistance in Staphylococcus aureus. Nature, Lond. 182, 602.

Schneider, W. C. (1957). Determination of nucleic acids in tissues by pentose analysis. Meth. Enzymol. 3, 680.

Tissières, A., Watson, J. D., Schlessinger, D. \& Hollingworth, B. R. (1959). Ribonucleoprotein particles from Escherichia coli. J. molec. Biol. 1, 221.

Tissiènes, A. (1959). Some properties of soluble ribonucleic acid from Escherichia coli. J. molec. Biol. 1, 365.

Wisseman, C. L., Jr., Smadel, J. E., Hahn, F. E. \& Hopps, H. E. (1954). Mode of action of chloramphenicol. I. Action of chloramphenicol on assimilation of ammonia and on synthesis of proteins and nucleic acids in Escherichia coli. J. Bact. 67, 662.

Yee, R. B., Pan, S. F. \& Gezon, H. M. (1962). Effect of chloramphenicol on protein and nucleic acid synthesis by Shigella flexneri. J. gen. Microbiol. 27, 521.

Yee, R. B., Gezon, H. M. \& MCEulrgotT, J. (1962). Ribonucleic acid synthesis in chloramphenicol-treated Shigella. Nature, Lond. 196, 66. 